PAULINA JABŁOŃSKA

Wydział Prawa Kanonicznego

Papieskiego Uniwersytetu Jana Pawła II w Krakowie

ORCID: 0000-0002-5514-3215

\title{
FORMALNY AKT WYSTĄPIENIA Z KOŚCIOŁA KATOLICKIEGO
}

Treść: Wstęp. - 1. Formalny akt wystąpienia z Kościoła według motu proprio Benedykta XVI Omnium in mentem. - 2. Formalny akt wystąpienia z Kościoła katolickiego w świetle Listu Okólnego Papieskiej Rady ds. Tekstów Prawnych z 13 marca 2006 roku. - 3. Zasady postępowania w sprawie formalnego aktu wystąpienia $\mathrm{z}$ Kościoła. - 4. Skutki formalnego aktu wystąpienia z Kościoła. - Zakończenie.

\section{Wstęp}

Odstąpienie od wiary i opuszczenie Kościoła nie jest zjawiskiem nowym. Współcześnie zjawisko to należy do tematów medialnych. Z przekazów medialnych można się dowiedzieć o wyrokach sądów administracyjnych a także o decyzjach Generalnego Inspektora Ochrony Danych Osobowych odnoszących się do tego zagadnienia. Artykuł ten będzie dotyczył formalnego aktu wystąpienia z Kościoła katolickiego. Ukaże on genezę tego sformułowania w dokumentach normatywnych Kościoła. O wadze tego zagadnienia świadczy także dokonana w roku 2009 nowelizacja przepisów Kodeksu Prawa Kanonicznego z 1983 roku, odnoszących się do m. in. do formalnego aktu wystąpienia z Kościoła katolickiego. 


\section{Formalny akt wystąpienia $\mathrm{z}$ Kościoła według motu proprio Benedykta XVI Omnium in mentem}

26 października 2009 r. papież Benedykt XVI ogłosił motu proprio Omnium in mentem ${ }^{1}$, na mocy którego usunął z treści Kodeksu wyrażenie Actus formalis defectionis ab Ecclesia catholica ${ }^{2}$. Wyrażenie to występowało w trzech kanonach tytułu VII Kodeksu, pierwszej części księgi czwartej, w całości poświęconego sakramentowi małżeństwa. Jednym z tych kanonów był kanon $1086 \$ 1$ - przeszkoda różnej wiary. W dawnym brzmieniu ${ }^{3}$ kanonu $1086 \$ 1$ mogliśmy przeczytać:

Nieważne jest matżeństwo między dwiema osobami, z których jedna została ochrzczona w Kościele katolickim lub była do niego przyjęta i nie odłaczyła się od niego formalnym aktem, a druga jest nieochrzczona.

Nowe brzmienie kanonu:

Nieważne jest małżeństwo między dwiema osobami, z których jedna została ochrzczona w Kościele katolickim lub była do niego przyjęta, a druga jest nieochrzczona.

Kościół katolicki od początku z niechęcią odnosi się do małżeństw mieszanych ${ }^{4}$, tym większego zagrożenia dopatruje się w zawieraniu małżeństw z nieochrzczonymi. Argumentując swoje stanowisko, powołuje się na fakt doskonałej jedności małżonków, która zostaje zachwiana, gdyż religia, którą różnią się małżonkowie należy do

\footnotetext{
${ }^{1}$ Benedy KT XVI, List apostolski motu proprio „Omnium in mentem” na temat zmian $w$ Kodeksie Prawa Kanonicznego, L’Osservatore Romano. Wydanie Polskie, 31 (2010), nr 5, s. 13-14.

${ }^{2}$ Tłumaczenie: formalny akt wystąpienia z Kościoła katolickiego.

${ }^{3}$ Przed zmianą dokonaną przez Benedykta XVI.

${ }^{4}$ T. Pawluk, Prawo kanoniczne według Kodeksu Jana Pawła II. Prawo małżeńskie, t. III, Olsztyn 1984, s. 133; M. ŻurowsKI, Kanoniczne prawo mał̇̇ńskie Kościoła katolickiego, Katowice 1987, s. 162.
} 
spraw niezwykle istotnych w życiu małżeństwa i rodziny ${ }^{5}$. Trudno zatem mówić o doskonałej jedności, gdy małżeństwo dzieli wyznawana wiara. Zapis kanonu 1086, w praktyce oznaczał, że katolika, który odstąpił od Kościoła aktem formalnym, nie obowiązywała przeszkoda zrywająca, o której mowa w paragrafie 1 tego kanonu.

Występowanie w omawianym kanonie interesującego nas wyrażenia powodowało wiele trudności w interpretacji wynikającego z niego prawa. W ogłoszonym przez Benedykta XVI motu proprio Omnium in mentem ${ }^{6}$ można przeczytać, że właśnie te trudności i niejasności skłoniły papieża do zmiany obowiązującego prawa, w wyniku której z kanonu 1086 został usunięty zapis o formalnym akcie wystąpienia z Kościoła katolickiego. Zaistniała zmiana pociągnęła za sobą całkowicie odmienne wymaganie dotykające osobę, która formalnym aktem odstąpiła od Kościoła.

Po wejściu w życie zmian dokonanych przez Benedykta XVI w prawie kanonicznym, formalny apostata ${ }^{7}$ podlega przeszkodzie różnej religii. Oznacza to, że małżeństwo katolika, który wystąpił z Kościoła katolickiego formalnym aktem, z osobą nieochrzczoną jest nieważne, jeżeli nie uzyskano odpowiedniej dyspensy, którą przewiduje prawo kościelne ${ }^{8}$.

Kolejnym kanonem jest kanon 1117 - dotyczący formy zawarcia małżeństwa, który stanowił:

Określona wyżej forma powinna być zachowana, jeśli przynajmniej jedna ze stron zawierajacych małżeństwo została ochrzczona $w$ Kościele katolickim lub została do niego przyjęta i nie wystapiła $z$ niego aktem formalnym, $z$ zachowaniem przepisów kan. $1127 \$ 2$.

\footnotetext{
${ }^{5}$ Por. Tamże, s. 163.

${ }^{6}$ Por. Benedy KT XVI, List apostolski motu proprio „Omnium in mentem”..., dz. cyt., s. 13.

${ }^{7} \mathrm{~W}$ niniejszym artykule, na określenie osoby, która formalnym aktem wystąpiła z Kościoła katolickiego, będą używane wyrażenia: formalny odstępca lub formalny apostata.

${ }^{8}$ Por. kan. $1086 \$ 2$ KPK z 1983 r.
} 
Nowe brzmienie kanonu:

Określona wyżej forma powinna być zachowana, jeśli przynajmniej jedna ze stron zawierajacych małżenstwo została ochrzczona w Kościele katolickim lub została do niego przyjęta, z zachowaniem przepisów kan. 1127 \$ 2.

Obowiązek zachowania formy kanonicznej znany był już w Kodeksie Piusa X i Benedykta XV z 1917 r. ${ }^{9}$ W nowym Kodeksie z 1983 r. wymagalność formy kanonicznej została ograniczona. Katolik, który formalnym aktem wystąpił z Kościoła, do ważności małżeństwa nie musiał zachować formy kanonicznej, o ile nie zawierał małżeństwa z katolikiem zobowiązanym do zachowania formy. Powód tej transformacji upatrywano we względach ekumenicznych ${ }^{10}$ oraz $\mathrm{w}$ trosce o niezwiększanie liczby małżeństw nieważnych ${ }^{11}$.

Małżeństwa zawierane przez formalnych apostatów często były narażone na nieważność. Człowiek, który wystąpił z Kościoła, na ogół nie chce mieć z nim nic wspólnego, dlatego też nie przestrzega następnie wymagań zachowania formy kanonicznej. Prawodawca chcąc sprostać wymaganiom osobom, które wystąpiły z Kościoła postanowił zwolnić ich z obowiązku zachowania formy kanonicznej.

Od chwili promulgacji Kodeksu Prawa Kanonicznego z 1983 r. katolików, którzy formalnym aktem wystąpili z Kościoła katolickiego do ważności zawieranego małżeństwa nie obowiązywało zachowanie przepisanej przez prawo formy kanonicznej ${ }^{12}$. Zmiana ta przyspo-

\footnotetext{
${ }^{9}$ Por. P. Hemperek, W. Góralski, F. PrzytuŁa, J. Bakalarz, Komentarz do Kodeksu Prawa Kanonicznego z 1983 r., t. 3, Redakcja Wydawnictw KUL, Lublin 1986, s. 299.

${ }^{10} \mathrm{~W}$ przypadku zawierania małżeństwa między katolikiem a niekatolikiem obrządku wschodniego forma kanoniczna nie jest konieczna do ważności małżeństwa, ale jedynie do jego godziwości. Warunkiem ważności jest obecność świętego szafarza. Por. kan. $1127 \$ 1$ KPK z 1983 r.

${ }^{11}$ T. Pawluk, Prawo Kanoniczne..., dz. cyt., s. 190.

${ }^{12}$ E. Sztafrowski, Podręcznik Prawa Kanonicznego, t. 4, Akademia Teologii Katolickiej, Warszawa 1986, s. 128-129.
} 
rzyła wiele trudności interpretacyjnych w pracy duszpasterskiej oraz praktyce sądów $^{13}$. Z tego powodu papież Benedykt XVI w ogłoszonym motu proprio, w którym zmienił treść omawianych kanonów (1086 $\S 1,1117,1124)$, usunął $\mathrm{w}$ nich zapis o formalnym akcie wystąpienia z Kościoła katolickiego.

Zmiana, której dokonał Benedykt XVI jest powrotem do praktyki, obowiązującej w Kodeksie z 1917 r. Według niej, katolik, który wystąpił z Kościoła aktem formalnym, był zobowiązany do zachowania formy kanonicznej co do ważności zawieranego małżeństwa ${ }^{14}$.

Ostatnim z omawianych kanonów jest kanon 1124, który mówi o małżeństwach mieszanych.

Małżeństwo między dwiema osobami ochrzczonymi, z których jedna została ochrzczona w Kościele katolickim lub po chrzcie zostata do niego przyjęta i formalnym aktem od niego się nie odłaczyła, druga zaś należy do Kościoła lub wspólnoty kościelnej nie mającej pełnej łączności z Kościołem katolickim, jest zabronione bez wyraźnej zgody kompetentnej władzy.

Nowe brzmienie kanonu:

Małżeństwo między dwiema osobami ochrzczonymi, z których jedna została ochrzczona w Kościele katolickim lub po chrzcie została do niego przyjęta, druga zaś należy do Kościoła lub wspólnoty kościelnej nie mającej petnej jedności z Kościołem katolickim, jest zabronione bez wyraźnej zgody kompetentnej władzy.

Ostatni kanon, reguluje zagadnienie małżeństw mieszanych. Chodzi o małżeństwo dwóch osób ochrzczonych, z których gdzie jedna

\footnotetext{
${ }^{13}$ Por. Benedy KT XVI, List apostolski motu proprio „Omnium in mentem”..., dz. cyt., s. 13.

${ }^{14}$ M. Żurowski, Kanoniczne prawo małżeńskie..., dz. cyt., s. 328.
} 
jest katolikiem, zaś druga członkiem Kościoła lub wspólnoty kościelnej niebędącej w pełnej jedności z Kościołem katolickim ${ }^{15}$.

Zgodnie z tym kanonem, zawieranie takich małżeństw jest zakazane bez wyraźnej zgody kompetentnej władzy kościelnej (zazwyczaj będzie to ordynariusz miejsca). Prawodawca nie obwarował tego zakazu klauzulą nieważności małżeństwa, przewidział jedynie sankcję niegodziwości ${ }^{16}$.

Zgodnie z kanonem 1124 Kodeksu Prawa Kanonicznego z 1983 r. (przed nowelizacją dokonaną przez Benedykta XVI) zakaz zawierania małżeństw mieszanych bez zgody ordynariusza nie obowiązywał nupturienta, który ochrzczony w Kościele katolickim, wystąpił następnie z niego formalnym aktem.

Podobnie jak w kanonach 1086 i 1117 analizowanych powyżej, prawo ułatwiało zawarcie małżeństwa przez osoby, które wystąpiły z Kościoła. Nowelizacja wszystkich trzech kanonów spowodowała, że osobę, która formalnym aktem odstąpiła od Kościoła, nadal obowiązuje zakaz zawierania małżeństw mieszanych bez wyraźnej zgody kompetentnej władzy kościelnej ${ }^{17}$.

Wyrażenie actus formalis defectionis ab Ecclesia catholica występowało w trzech kanonach nowego Kodeksu Jana Pawła II. Klauzula ta wyjmowała z zakazu zawarcia małżeństwa mieszanego, zachowania formy kanonicznej a także obowiązywania przeszkody różnej religii osobę, która formalnym aktem odłączyła się od Kościoła katolickiego.

Przyczynami wprowadzenia takiej klauzuli w nowym Kodeksie były względy ekumeniczne a także chęć ograniczenia zawierania nieważnych małżeństw. Ze względu na pojawienie się coraz większych trudności z interpretacją tej klauzuli, Benedykt XVI znowelizował kanony zawierające omawiane wyrażenie wykreślając je z treści tych kanonów.

\footnotetext{
${ }^{15}$ Por. kan. 1124 KPK z 1983 r.

${ }^{16}$ Por. W. Góralski, Kościelne prawo małżeńskie, Płockie Wydawnictwo Diecezjalne, Płock 1987, s. 97.

${ }^{17}$ Zgodnie z zasadą semel catholicus, semper catholicus.
} 
Aktualizacja dokonana przez motu proprio Omnium in mentem nie tylko wprowadziła zmiany w prawie małżeńskim ale usunęła także z Kodeksu wyrażenie actus formalis defectionis ab Ecclesia catholica.

Pomimo, iż w Kodeksie sformułowanie to nie występuje, istnieje coraz częstsza praktyka wystąpień z Kościoła formalnym aktem. Skutkiem tego actus formalis defectionis ab Ecclesiae catholica zaczęto klasyfikować jako czwarte z przestępstw przeciwko wierze i jedności Kościoła, obok apostazji, herezji i schizmy ${ }^{18}$.

\section{Formalny akt wystąpienia $\mathrm{z}$ Kościoła katolickiego w świetle Listu Okólnego Papieskiej Rady ds. Tekstów Prawnych z 13 marca 2006 roku}

13 marca 2006 r. Papieska Rada ds. Tekstów Prawnych wydała List Okólny dotyczący problemu wystąpienia z Kościoła katolickiego aktem formalnym, skierowany do konferencji episkopatów poszczególnych krajów ${ }^{19}$.

List Okólny składa się ze wstępu, w którym omówiono powody wydania Listu a także proces jego powstawania, treści zasadniczej dokumentu, która została podana w 7 punktach oraz krótkiego zakończenia. Dokument został opatrzony podpisami przewodniczącego i sekretarza Papieskiej Rady ds. Tekstów Prawnych, nosi też aprobatę Papieża Benedykta XVI.

Do listu zostały dołączone trzy pisma stanowiące: odpowiedź w języku angielskim skierowaną do jednej z konferencji biskupów oraz dwa dalsze pisma w języku włoskim a także hiszpańskim dotyczące dalszych wyjaśnień poruszonego problemu.

Dokument stanowi komunikat, wytłumaczenie zaistniałych wątpliwości związanych z wyrażeniem „wystąpienie z Kościoła katolickiego aktem formalnym” podane z mocą autorytetu Papieskiej

\footnotetext{
${ }^{18}$ Por. W. Wenz, Apostazja i formalny akt wystąpienia $z$ Kościoła. Zasady postępowania wświetle norm kościelnych, Prawo i Kościół t. 2, 2010, s. 41.

${ }^{19}$ Por. Papieska Rada Ds. Tekstów Prawnych, List Okólny Papieskiej Rady ds. Tekstów Prawnych, 13.03.2006, Miesięcznik Pasterski Płocki, 91 (2006), s. 242-244.
} 
Rady ds. Tekstów Prawnych oraz Kongregacji Nauki Wiary i papieża Benedykta XVI.

Papieska Rada ds. Tekstów Prawnych przypomina w Liście Okólnym o niepodważalnej prawdzie przynależności do Kościoła opierającej się na sakramencie chrztu świętego. Poprzez ten sakrament tworzy się pomiędzy człowiekiem i Kościołem niezatarta więź, dlatego też wspólnota z Kościołem ma charakter ontologiczny i nieodwracalny. Jednocześnie prawo kościelne dopuszcza możliwość formalnego aktu wystąpienia z Kościoła katolickiego. Akt ten należy rozumieć nie jako definitywne zerwanie ze wspólnotą Kościoła, ale jako przyjęcie do urzędowej wiadomości woli człowieka, który nie chce mieć z Kościołem nic wspólnego i pragnie zerwania więzów formalnych, które go z nim łączą. Aby do tego aktu doszło muszą być spełnione trzy fundamentalne elementy:

a. wewnętrzne postanowienie opuszczenia Kościoła katolickiego;

b. wykonanie i zamanifestowanie zewnętrzne takiego postanowienia;

c. przyjęcie ze strony kompetentnego autorytetu kościelnego takiego postanowienia ${ }^{20}$.

Formalny akt wystąpienia ukazuje się jako konkretna forma zerwania wspólnoty z Kościołem katolickim. Trzeba pamiętać, że zainteresowany w dalszym ciągu jest członkiem tej wspólnoty, jego uczestnictwo ma bowiem charakter obiektywny. Niezatarta pieczęć sakramentalna jest inherentna, nie może jej złamać nawet zaistniały akt wystąpienia z Kościoła.

Formalny akt nie jest tylko czysto prawno administracyjnym aktem, ale w swojej istocie zakłada rzeczywiste odłączenie od konstytutywnych elementów życia Kościoła. Posiada więc on charakter apostazji (zgodnie z kan. $751 \mathrm{KPK}$ to całkowite porzucenie wiary chrześcijańskiej, dokonane przez ochrzczonego i zarazem członka

\footnotetext{
${ }^{20}$ Por. T. Rozkrut, Warunki formalnego wystąpienia z Kościoła Katolickiego w perspektywie zawarcia małżeństwa kanonicznego, w: Przebóstwiać to, co ludzkie. Księga pamiątkowa ku czci Księdza Biskupa Władysława Bobowskiego, red. S. Sojka, J. Stala, Tarnów 2007, s. 399-407.
} 
Kościoła katolickiego), herezji (zgodnie z kan. 751 KPK to uporczywe, po przyjęciu chrztu, zaprzeczanie prawdzie chrześcijańskiej, w którą należy wierzyć wiarą boską i katolicką, albo uporczywe poddawanie jej w wątpliwość), schizmy (zgodnie z kan. 751 KPK schizma stanowi uporczywą odmowę uznania przez katolika zwierzchnictwa Biskupa Rzymskiego lub trwania w integralnej wspólnocie z członkami Kościoła katolickiego, którzy uznają zwierzchnictwo Biskupa Rzymskiego). Nie dokonanie choćby jednego z tych przestępstw oznacza, iż nie nastąpił akt formalnego wystąpienia z Kościoła, lecz, jeżeli dokonanie jednego $\mathrm{z}$ ww. przestępstw nie zostało ujawnione i przyjęte przez kompetentną władzę kościelną, nie ma mowy o formalnym akcie wystąpienia z Kościoła katolickiego.

Wymóg ujawnienia decyzji wystąpienia z Kościoła przed kompetentną władzą kościelną w świetle prawodawstwa mającego związek $\mathrm{z}$ omawianym problemem stanowi novum. Tylko kompetentna władza kościelna może przyjąć decyzję i orzec, czy faktycznie zostały spełnione elementy konstytutywne formalnego aktu wystąpienia z Kościoła katolickiego.

\section{Zasady postępowania w sprawie formalnego aktu wystąpienia $\mathrm{z}$ Kościoła}

27 września 2008 r. Konferencja Episkopatu Polski, zebrana na 345 Zebraniu Plenarnym w Białymstoku, wydała Zasady postępowania $w$ sprawie formalnego aktu wystąpienia $z$ Kościoła ${ }^{21}$.Celem tego dokumentu jest ułatwienie jednolitego stosowania wskazań PRTP dotyczących formalnego aktu wystąpienia z Kościoła.

Treść dokumentu Konferencji Episkopatu Polski została zawarta w 22 punktach, w których podkreślono, iż formalny akt wystąpienia z Kościoła jest procesem złożonym. Można w nim wyróżnić: 1) czynności poprzedzające przyjęcie formalnego aktu wystąpienia z Kościoła; 2) czynności związane w sposób bezpośredni z formalnym

\footnotetext{
${ }^{21}$ Por. Konferencja Episkopatu Polski, Zasady postępowania $w$ sprawie formalnego aktu wystąpienia z Kocioła, Akta Konferencji Episkopatu Polski 14 (2009), s. 89-91.
} 
aktem; 3) czynności, które należy koniecznie wykonać po odebraniu formalnego aktu wystąpienia z Kościoła ${ }^{22}$. Jedną z pierwszych czynności poprzedzających przyjęcie formalnego aktu jest stwierdzenie, czy osoba, wobec której składa się oświadczenie woli wystąpienia z Kościoła jest osobą kompetentną. Zgodnie z tym dokumentem akt może zostać przyjęty jedynie przez własnego ordynariusza lub proboszcza. Konferencja Episkopatu Polski wskazuje, że chodzi tutaj o proboszcza kanonicznego miejsca zamieszkania, stałego lub tymczasowego ${ }^{23}$ osoby chcącej dokonać apostazji.

Istnieje możliwość, aby akt wystąpienia mógł być przyjęty przez innego duchownego niż wspomniany proboszcz, czy ordynariusz. W takiej sytuacji duchowny ten powinien otrzymać delegację do ogółu spraw (lub do tej konkretnej) od proboszcza lub ordynariusza zgodnie $\mathrm{z}$ zasadami prawa ${ }^{24}$. Kolejnym istotnym elementem jest potwierdzenie zdolności prawnej zainteresowanego. Zdolną prawnie ${ }^{25}$ będzie osoba pełnoletnia, która osobiście wyrazi swoją chęć wystąpienia z Kościoła.

Do czynności poprzedzających akt formalnego wystąpienia należy zaliczyć także rozmowę duszpasterską. Punkt 8 Zasad mówi wyraźnie, że powinna to być rozmowa osobista, pełna troski i życzliwości.

Głównym celem tej rozmowy jest próba przekonania formalnego apostaty do rezygnacji z chęci wystąpienia z Kościoła. Służyć ma temu poznanie prawdziwych motywacji tego czynu, dla których ktoś chce wystąpić z Kościoła.

Zgodnie z nr 9 Zasad proboszcz w trakcie rozmowy duszpasterskiej lub przy innej okazji ma obowiązek poinformować zainteresowanego o kanonicznych skutkach formalnego aktu wystąpienia z Kościoła. Przede wszystkim chodzi tu o karę ekskomuniki latae sententiae, która skutkuje: niemożnością sprawowania i przyjmowania

\footnotetext{
${ }^{22}$ Taki podział proponuje T. JAKUBIAK, Istotne elementy konstytutywne formalnego aktu wystąpienia $z$ Kościoła oraz czynności związane z jego przyjęciem, Ateneum Kapłańskie, 3 (2009), s. 323.

${ }^{23}$ Por. kan. $102 \S 1, \S 2, \S 3$ KPK z 1983 r.

${ }^{24}$ Por. kan.137 KPK z 1983 r.

${ }^{25}$ Por. kan. 98 § $1, \$ 2$ KPK z 1983 r.
} 
sakramentów oraz sprawowania sakramentaliów; zakazem udziału ministerialnego w obrzędach kultu; zakazem wykonywania funkcji w Kościele oraz pozbawieniem pogrzebu kościelnego.

Zasady w punkcie 11 Konferencji Episkopatu Polski zalecają, aby występującemu szczegółowo wyjaśnić, iż chrzest jaki przyjął, jest wydarzeniem, którego nie można wymazać ani z historii ani z księgi ochrzczonych.

Dobrze jest też wyjaśnić wiernemu, że osoba, która wystąpiła z Kościoła katolickiego nie jest podporządkowana przepisom o formie kanonicznej nieodzownej do ważności małżeństwa w sytuacji ślubu $\mathrm{z}$ niekatolikiem ${ }^{26}$.

Dalsza analiza dokumentu Konferencji Episkopatu wyodrębnia czynności bezpośrednio związane $\mathrm{z}$ formalnym aktem wystąpienia z Kościoła (punkty 4-7 Zasad).

Proces właściwy formalnego aktu należy rozpocząć od weryfikacji dokumentów tożsamości występującego a także dwojga świadków. Dokument wymaga, aby byli oni pełnoletni (jeśli to możliwe jednym ze świadków winien być rodzic lub rodzic chrzestny). Warto zauważyć, że świadkowie nie ponoszą żadnych kar za udział w omawianym akcie ${ }^{27}$.

Proboszcz powinien także upewnić się, iż pisemna deklaracja apostaty jest zgodna $\mathrm{z}$ wymogami prawa i zawiera wszystkie istotne elementy, tj. dane personalne osoby, która wyraża chęć wystąpienia z Kościoła oraz obecnych świadków, jasne i wyraźne wyrażenie woli wystąpienia z Kościoła, a także wskazanie na motyw i powód takiej decyzji, deklarację potwierdzającą świadomość konsekwencji dokonywanego czynu oraz informację o dobrowolności podejmowanej decyzji. Do spełnienia wymogów formalnego kształtu oświadczenia, winno ono także zawierać dane o dacie i parafii chrztu apostaty.

\footnotetext{
${ }^{26}$ Por. kan. 1117 KPK z 1983 r.; A. Stankiewicz, Instrukcja, w: A. Dzięga, M. Greszata, W. Kiwior, T. Rozkrut, H. Stawniak, R. Sztychmiler, W. Wenz, A. Stankiewicz, Komentarz do Instrukcji procesowej „Dignitas connubii”, Sandomierz 2007, s. 28-31.

${ }^{27}$ Por. W. Wenz, Apostazja i formalny akt wystąpienia z Kościoła. Zasady postępowania wświetle norm kościelnych, Prawo i Kościół, t. 2, 2010, s. 36.
} 
Po sprawdzeniu wszystkich niezbędnych danych, apostata i świadkowie składają własnoręczne podpisy na oświadczeniu wyrażającym wolę wystąpienia $\mathrm{z}$ Kościoła, a następnie akt ten zostaje potwierdzony podpisem proboszcza wraz $z$ datą oraz pieczęcią parafialną ${ }^{28}$.

Po spełnieniu powyższych etapów aktu formalnego istnieją jeszcze czynności, do których zobligowany jest proboszcz. Mówi o nich punkt 12 Zasad. Pierwszą czynnością po dokonaniu powyższego aktu wystąpienia z Kościoła jest sporządzenie uwierzytelnionej kopii aktu i przekazanie jej do kurii swojej diecezji. Kuria diecezjalna po zbadaniu sprawy, czy formalny akt jest prawnie skuteczny, poleca proboszczowi miejsca chrztu odstępcy dokonanie odpowiedniej adnotacji w księdze ochrzczonych, a także we wszystkich duplikatach ksiąg metrykalnych. Proboszcz miejsca dokonania aktu formalnego ma obowiązek zamieszczenia odpowiedniej uwagi w kartotece parafialnej, a oryginał dokumentu przechowywać w archiwum parafialnym. W sytuacji gdy, odstępca przyjął chrzest w parafii należącej do innej diecezji, kuria przesyła właściwą informację do kurii diecezji chrztu odstępcy.

Świadectwo chrztu jest jedynym dokumentem potwierdzającym dokonanie aktu wystąpienia z Kościoła (Zasady, pkt 15). Może się zdarzyć, że apostata zażąda dokumentu potwierdzającego jego odejście od Kościoła katolickiego. W takim przypadku parafia chrztu wydaje odpis aktu chrztu opatrzony adnotacją o dokonanym formalnym akcie wystąpienia z Kościoła na prośbę odstępcy ${ }^{29}$.

\section{Skutki formalnego aktu wystąpienia z Kościoła}

Formalny akt wystąpienia z Kościoła katolickiego, będący szczególną formą apostazji, niesie za sobą poważne konsekwencje prawno-duszpasterskie.

\footnotetext{
${ }^{28}$ Por. T. JA КUвіAк, Istotne elementy konstytutywne formalnego aktu wystąpienia z Kościoła oraz czynności związane z jego przyjęciem, Ateneum Kapłańskie, 3 (2009), s. 327.

${ }^{29}$ Por. W. Wenz, Apostazja i formalny akt wystąpienia z Kościoła. Zasady postępowania wświetle norm kościelnych, Prawo i Kościół, t. 2, 2010, s. 39.
} 
Przede wszystkim chodzi tu o karę ekskomuniki latae sententiae ze wszystkimi jej następstwami oraz wszelkie konsekwencje związane z zawarciem małżeństwa a także inne administracyjne skutki.

Kanon 1311 KPK z 1983 r. mówi o prawie Kościoła do stosowania sankcji karnych. Jest to jego (Kościoła) prawo wrodzone i własne ${ }^{30}$.

Prawo kościelne wyróżnia dwa rodzaje ekskomuniki: wymierzoną (ferendae sententiae) oraz wiążącą mocą samego prawa (latae sententiae) $)^{31}$.

W przypadku przestępstwa apostazji a także formalnego aktu wystąpienia z Kościoła katolickiego mamy do czynienia z zaciągnięciem ekskomuniki latae sententiae. Zaczyna ona obowiązywać z chwilą popełnienia przestępstwa, jeżeli wyraźnie zaznaczono to w ustawie lub nakazie prawnym ${ }^{32}$.

Karze ekskomuniki podlega osoba fizyczna, ochrzczona, w pełni rozwoju umysłowego, należąca do Kościoła, która popełniła przestępstwo zagrożone ekskomuniką. Kara ta trwa tak długo, jak długo istnieje upór ze strony sprawcy ${ }^{33}$. Dopóki sprawca trwa w danym czynie i nie stara się zmienić stanowiska, dopóty znajduje się pod karą ekskomuniki. Ekskomunika wywołuje następujące skutki ${ }^{34}$ :

- zakaz uczestnictwa w sprawowaniu Eucharystii lub innych obrzędach kultu; sprawowania sakramentów i sakramentaliów

- zakaz przyjmowania sakramentów

- $\quad$ zakaz sprawowania urzędów kościelnych, posług oraz wszelkich innych zadań.

W przypadku, gdy kara latae sententiae zostanie zadeklarowana ${ }^{35}$, do powyżej wymienionych skutków dodać należy kolejne:

\footnotetext{
${ }^{30}$ Por. R. Rувак, Ekskomunika „latae sententiae” za popetnienie przestępstwa apostazji, herezji i schizmy, Prawo i Kościół, t. 1, 2006, s. 37-57.

${ }^{31}$ Por. kan. 1314 KPK z 1983 r.

${ }^{32}$ Por. kan. 1364 \& 1 KPK z 1983 r.

${ }^{33}$ Por. R. Rувак, Ekskomunika..., dz. cyt., s. 44.

${ }^{34}$ O skutkach ekskomuniki mówi w całości kanon 1331 KPK z 1983 r.

${ }^{35}$ Por. kan. $1331 \$ 2$ KPK z 1983 r.
} 
- wykonywanie wszelkich aktów jurysdykcyjnych lub rządzenie jest niegodziwe i nieważne ${ }^{36}$

- $\quad$ zakaz korzystania $z$ otrzymanych przywilejów osobistych ${ }^{37}$

- zakaz otrzymywania godności i zadań w Kościele ${ }^{38}$

- zakaz pobierania dochodów z tytułu godności, zadań pełnionych w Kościele, pensji kościelnej ${ }^{39}$

- niezdolność do udziału w głosowaniach przy wyborach na urzędy kościelne ${ }^{40}$.

Kara ekskomuniki odbiera przestępcy prawo do decydowania w sprawach kościelnych, które przejawia się formą głosowania:

- niemożność przyjęcia do stowarzyszenia publicznego wiernych ${ }^{41}$

- $\quad$ wydalenie z publicznego stowarzyszenia wiernych ${ }^{42}$

- wydalenie z instytutu zakonnego ${ }^{43}$

- apostata nie może zostać nauczycielem akademickim katolickiego uniwersytetu ${ }^{44}$

- $\quad$ nie może przyjąć święceń ${ }^{45}$

- nie może wykonywać zadań wynikających z przyjętych święceńn ${ }^{46}$

- $\quad$ pozbawiony jest pogrzebu katolickiego, jeśli przed śmiercią nie dał oznak pokuty ${ }^{47}$.

W celu uzyskania najwyraźniejszego obrazu konsekwencji formalnego aktu wystąpienia z Kościoła katolickiego, popatrzmy na zbiór sankcji przewidzianych za to przestępstwo przez pryzmat sakramentów. W szczególności będą nas interesować sakramenty

\footnotetext{
${ }^{36}$ Por. kan. $1331 \S 2,2^{\circ}$ KPK z 1983 r.

${ }^{37}$ Por. kan. $1331 \$ 2,3^{\circ} \mathrm{KPK}$ z 1983 r.

${ }^{38}$ Por. kan. $1331 \$ 2,4^{\circ}$ KPK z 1983 r.

${ }^{39}$ Por. kan. $1331 \$ 2,5^{\circ} \mathrm{KPK}$ z 1983 r.

${ }^{40}$ Por. kan. $149 \$ 1$ KPK z 1983 r.

${ }^{41}$ Por. kan. $316 \$ 1$ KPK z 1983 r.

${ }^{42}$ Por. kan. $316 \$ 2$ KPK z 1983 r.

${ }^{43}$ Por. kan. $694 \$ 1$ KPK z 1983 r.

${ }^{44}$ Por. kan. 810 \$ 1 KPK z 1983 r.

${ }^{45}$ Por. kan. 1041 KPK z 1983 r.

${ }^{46}$ Por. kan. $1044 \$ 1$ KPK z 1983 r.

${ }^{47}$ Por. kan. 1184 § 1 KPK z 1983 r.
} 
wtajemniczenia chrześcijańskiego (chrzest, bierzmowanie i Eucharystia) oraz sakrament małżeństwa.

Karze ekskomuniki podlegają wyłącznie ochrzczeni wierni, którzy dopuścili się konkretnego czynu, który pociąga za sobą tę karę. Z tego wynika, że pozbawienie kogoś prawa do chrztu nie może być skutkiem ekskomuniki. Wszelkie sankcje związane z chrztem dotyczą albo szafarza albo rodzica chrzestnego.

Apostata, zgodnie z Instrukcja $q^{48}$ Konferencji Episkopatu Polski z 1975 r. oraz kanonem $874 \$ 4 \mathrm{KPK}$, nie może zostać rodzicem chrzestnym. Tylko w sytuacji szczególnej ${ }^{49}$ może być świadkiem ${ }^{50}$ sakramentu chrztu.

Jeśli chodzi o szafarza, to może nim zostać apostata, pod warunkiem, że posiada intencję ochrzczenia dziecka zgodnie $\mathrm{z}$ rozumieniem Kościoła katolickiego ${ }^{51}$. Takiego szafarza zwykło określać się nadzwyczajnym, bo zastępuje z poważnych powodów zwyczajnego w sytuacji nadzwyczajnej. Prawo apostaty do udzielenia chrztu w sytuacji wyższej konieczności ma swoją podstawę w kanonie $861 \S 2 \mathrm{KPK}$, dającym prawo udzielania sakramentu chrztu każdemu człowiekowi.

Następnym sakramentem wtajemniczenia chrześcijańskiego jest bierzmowanie. Nie można dopuścić do sakramentu człowieka, który jest apostatą. Tradycyjnie szafarzem bierzmowania jest biskup, jednak zdarza się, że inny kapłan otrzymuje delegację do udzielenia tego sakramentu. W każdej sytuacji, czy to będzie biskup, czy też inny duchowny upoważniony do udzielenia bierzmowania, a będący apostatą, nie może on udzielić sakramentu dojrzałości chrześcijańskiej,

\footnotetext{
${ }^{48}$ Konferencja Episkopatu Polski, Instrukcja duszpasterska Episkopatu o udzielaniu sakramentu chrztu świętego dzieciom (1975), w: Dokumenty duszpastersko-liturgiczne Episkopatu Polski (1966-1998), red. Cz. Krakowiak, L. Adamowicz, Lublin 1999, s. 19-26.

${ }^{49}$ Taką sytuacją szczególną będzie zagrożenie życia nieochrzczonego dziecka.

${ }^{50}$ Rolą świadka, przy nieobecności rodziców chrzestnych, jest stwierdzenie udzielonego chrztu zgodnie z kanonem 875 KPK z 1983 r.

${ }^{51}$ Jeżeli będzie miał intencję udzielenia chrztu $\mathrm{z}$ wody i wypowie formułę trynitarną, np. N. ja ciebie chrzczę w imię Ojca i Syna i Ducha Świętego.
} 
podobnie jak i innych sakramentów. Akt bierzmowania udzielany przez apostatę będzie niegodziwy ${ }^{52}$.

Zostaje jeszcze kwestia świadka do bierzmowania. Prawo kościelne odmawia apostatom bycia świadkiem w sakramencie dojrzałości chrześcijańskiej. Rolą świadka do bierzmowania jest przypominanie bierzmowanemu wszystkich zadań, do wypełnienia których zobowiązał się w czasie liturgii bierzmowania. Świadek apostata nie może pełnić tej funkcji należycie, ponieważ zamiast zachęcać, istnieje obawa, że będzie odwodzić bierzmowanego od realizacji powierzonych mu zadań.

Ostatnim sakramentem inicjacji chrześcijańskiej jest Eucharystia. Apostata, zgodnie ze skutkami ekskomuniki nie może uczestniczyć w spełnianiu ofiary eucharystycznej. Zakaz obejmuje również pełne uczestnictwo w sprawowanej Mszy Świętej tj. zakaz przyjmowania Komunii Świętej w każdej postaci (ciała i Krwi Pańskiej).

Osoba, która całkowicie porzuca Kościół katolicki nie może być szafarzem zwyczajnym ani nadzwyczajnym Komunii Świętej. Z niemożności pojednania wypływa zakaz przyjmowania Komunii Świętej (apostata nie może przyjmować sakramentów, a więc i uzyskać rozgrzeszenia w sakramencie spowiedzi).

Apostata nie ma także możliwości korzystania z kolejnych sakramentów, jak spowiedź czy namaszczenie chorych. W tę logikę prawną wpisuje się jeszcze sakrament święceń. Zgodnie z prawem kościelnym ${ }^{53}$, osoba odstępująca od wiary, nie może przystąpić do święceń w jakimkolwiek stopniu. Jeżeli szafarz święceń jest apostatą to udziela on ich nieważnie.

Inaczej ma się rzecz z ostatnim z sakramentów świętych - małżeństwem. Ten sakrament nie jest obwarowany zakazem wynikającym z kary ekskomuniki w przeciwieństwie do poprzednich. Oznacza to, że osoba, która wystąpiła z Kościoła katolickiego ma możliwość zawarcia ważnego małżeństwa, nawet kościelnego ${ }^{54}$.

\footnotetext{
${ }^{52}$ Zakaz, aby powodował nieważność, musi być wyraźnie stwierdzony w ustawie. Por. kan. 10 KPK z 1983 r.

${ }^{53}$ Por. kan. $1041,2^{\circ}$ KPK z 1983 r.

${ }^{54}$ Por. kan. $1071 \S 1,5^{\circ}$ KPK z 1983 r.
} 
Po wejściu w życie zmian w prawie kanonicznym dokonanych przez Benedykta XVI ${ }^{55}$, formalnego apostatę podczas zawierania małżeństwa co do jego ważności obowiązuje zachowanie formy kanonicznej, istnieje również przeszkoda różnej religii oraz do godziwości zawieranego małżeństwa konieczna jest zgoda własnego ordynariusza na małżeństwo mieszane ${ }^{56}$.

\section{Zakończenie}

Celem niniejszego artykułu było określenie natury Actus formalis defectionis ab Ecclesia catholica. Akt formalnego wystąpienia określony został przez Papieską Radę ds. Tekstów Prawnych jako nowe i różne od innych sposobów notoryjne odejście od wiary. Naturę aktu formalnego wystąpienia tworzą trzy elementy konstytutywne, podane przez Papieską Radę ds. Tekstów Prawnych z 13 marca 2006 r. Aby można było mówić o ważnym i zaistniałym actus formalis defectionis ab Ecclesia catholica, muszą być spełnione formalne wymogi. Decyzja o wystąpieniu z Kościoła musi być umotywowana chęcią zerwania więzi ze wspólnotą Kościoła, wyznawaną wiarą, sakramentami oraz zwierzchnictwem hierarchii kościelnej. Tak podjętą decyzję należy wyrazić w formie pisemnej bądź osobiście zademonstrować przedstawicielowi władzy kościelnej - własnemu ordynariuszowi lub proboszczowi. Decyzja wraz z potwierdzającym ją pismem musi zostać przez kompetentną władzę kościelną przyjęta, co odbywa się poprzez sporządzenie adnotacji w księdze metrykalnej parafii chrztu. W ten sposób przeprowadzony akt wystąpienia można uznać za ważnie dokonany i pociągający za sobą konsekwencje kanoniczno - prawne. Każdy akt formalnego wystąpienia z Kościoła zakłada przestępstwo apostazji, herezji lub schizmy. Konsekwencjami

\footnotetext{
${ }^{55}$ Benedykt XVI usunął z kanonów Kodeksu Prawa Kanonicznego (1086 \$ 1, 1117, 1124) zwrot „formalny akt wystąpienia z Kościoła katolickiego”.

${ }^{56}$ Por. T. JакивіAк, Prawno-liturgiczne aspekty zawierania małżeństw z osobami, które formalnym aktem wystąpiły z Kościoła, w: U. Nowicka (red.), Kanoniczno liturgiczne aspekty zawierania małżeństw mieszanych i im podobnych, Warszawa 2014, s. 41-67.
} 
kanoniczno - prawnymi są więc ekskomunika latae sententiae, skutki związane $\mathrm{z}$ zawarciem małżeństwa a także inne następstwa natury prawnej. Actus formalis defectionis ab Ecclesia catholica, apostazja, herezja, schizma lub jakakolwiek inna forma opuszczenia Kościoła nie sprawiają, że katolik przestaje być katolikiem. Niezatarte znamię sakramentu chrztu świętego, które wyciska na człowieku niezmywalną pieczęć sprawia bowiem, że semel catholicus, semper catholicus.

\section{The formal act of defection from the Catholic Church}

The article presents problem of a formal act of defection from the Catholic Church. Article describe regulations based on the Catholic Church documents such as: Code of Canon Law (1983), Pontifical Council for Legislative Texts (2006), motu proprio of Benedict XVI Omnium in mentem (2009) and the documents of Polish Bishops Conference. At the end of the article it describes the effects of the formal act of defection from the Catholic Church.

SŁOWA KLUCZOWE: prawo kanoniczne; forma kanoniczna; interpretacja; Kościół katolicki; akt formalny; katolicyzm

KeYwords: canon law; canonical form; interpretation; Catholic Church; formal act; Catholicism

\section{Nota o AUTORzE}

Dr Paulina JabŁońska - ukończyła studia magisterskie na Wydziale Prawa i Administracji Krakowskiej Akademii im. Andrzeja Frycza Modrzewskiego w Krakowie, a także w 2012 roku studia podyplomowe z Prawa Pracy na Wydziale Prawa i Administracji Uniwersytetu Warszawskiego oraz w 2013 roku studia podyplomowe z Pedagogiki dla Nauczycieli bez Przygotowania Pedagogicznego na Wydziale Pedagogicznym Uniwersytetu Warszawskiego. W latach 2012-2016 odbywała studia doktoranckie na Wydziale Prawa i Administracji Uniwersytetu Jagiellońskiego, które łączyła z pracą w Sądzie Okręgowym dla Warszawy Pragi oraz w Sądzie Okręgowym dla Warszawy w Warszawie. W 2019 roku obroniła pracę doktorską na Uniwersytecie Jagiellońskim w Krakowie. Obecnie studentka Prawa Kanonicznego na Wydziale Prawa Kanonicznego Uniwersytetu Jana Pawła II w Krakowie. 